Mikkel Thelle er adjunkt på Institut for Kultur og Samfund, Aarhus Universitet og leder af Dansk Center for Byhistorie ved universitetet og Den Gamle By. I 2013 blev han Ph.d. i historie med afhandlingen "København 1900. Rådhuspladsen som laboratorium for den moderne bys offentlige rum".

\title{
"ET SPEJL MED MANGE HUNDREDE FLADER" Elektrificeringen af byen og kroppen omkring 1900
}

Elektrificering er en central del af den moderne bys kulturhistorie. Artiklen undersøger med udgangspunkt i København, hvordan elektricitetens tidlige udvikling 1880-1914 deltog i forandringen af kroppen såvel som byens offentlige rum.

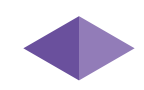

B egrebet elektrificering har flere betydninger alt efter hvem, der taler. Således kan det i tekniske termer være en overgang til elektrisk drivkraft frem for f.eks. damp, eller det kan betyde, at et legeme tilføres elektrisk energi. Der er dog også en bredere betydning: at noget bliver praktiseret og italesat som elektrisk. Hvis man skal diskutere elektrificering som et kulturhistorisk fænomen, kan dette perspektiv være frugtbart, om end ikke helt løsrevet fra den mere traditionelle definition.

Da elektriciteten blev indført i København omkring 1900, blev byen elektrificeret i alle de nævnte betydninger, men for at belyse den mangfoldighed af konsekvenser elektriciteten fik, må vi prøve at folde begrebet ud. Hvad er en sådan elektrificering af byen, hvis vi ser det kulturhistorisk som en sammenføjning af tekst, materialitet og praksis? ${ }^{1}$ I forlængelse af det kan man også spørge, hvad en sådan udfoldning kan bidrage med for en byhistorie på tværs af teknologi- og kulturhistorie. Det er disse spørgsmål, artiklen vil undersøge, og som et metodisk spørgsmål

1 Sammenføjning er et forsøg på at oversætte "assemblage" i den betydning det har hos Manuel de Landa. De Landa, 2007. 
vil jeg prøve at sidestille to figurer, der tidligere har været undersøgt hver for sig: byens og kroppens rum. Besvarelsen af spørgsmålet knytter sig til spørgsmålet om hvordan elektrificering kan betragtes kulturhistorisk, og hvis man skal følge sammenføjningsideen, indebærer svaret en inddragelse af et heterogent kildemateriale.

Metodisk bevæger artiklen sig derfor i forskellige kildegrupper. En samling af væsentlige artikler fra danske elektrotekniske tidsskrifter er platformen her, i hovedsagen stillet til rådighed af historiker Ole Hyldtoft, men for udvalg og brug er ansvaret kun forfatterens. Samlingen repræsenterer en central del af diskussionen blandt den elektrotekniske elite i København særligt i årene omkring 1900. For den mere offentlige diskussion er brugt avisartikler fra danske aviser og formiddagsblade. ${ }^{2}$ Endelig er udvalgt en række litterære og medicinske tekster, der forholder sig direkte eller indirekte til elektriciteten. Dele af artiklen er bygget på sekundærlitteratur og er som sådan et forsøg på at sætte den teknologihistoriske behandling af elektrificeringen i forhold til den by- og kulturhistoriske forskning, der relaterer sig til samme emne. Vi kan begynde med en lille notits i et populært københavnsk formiddagsblad lige efter 1900, hvor byen og kroppen kobles i et usædvanligt forsøg:

\section{Selvmord a la Mode}

Hvilket Raffinement! Med en Staaltraad i hvis ene Ende var fastgjort en Vægt, stillede Manden sig i Positur midt paa Kørebanen og forsøgte nu ved at kaste Staaltraaden op paa de elektriske Traade som Sporvognene benytter at forskaffe sig et kraftigt elektrisk Pulver - kraftigt nok til at bringe ham derhen hvor der er Fred og Idel Glæde ... det hed sig i øvrigt, at Selvmorderen var en fra Mariendalsvej hjemmehørende teologisk Kandidat, der lider under Religionsskrupler. ${ }^{3}$

Et moderigtigt selvmord forsøgt ved at føre strøm gennem kroppen. Offentlighed, krop og teknologi sammenblandet i et mikroskopisk optrin, kort efter at elektriciteten for alvor havde gjort sit indtog i København. Uden at tillægge den for stor kildeværdi kan man sige, at denne historie ville have været umulig at fortælle bare ti år tidligere, af forskellige grunde. Både diskursivt, materielt og hvad angår hverdagslivet skete der med elektrificeringen af byen en række forandringer, store som små, over kort tid. Hvis man ville skrive en teknologisk kulturhistorie, og denne havde et kapitel om den moderne by, kunne disse forandringer have en central plads her. En sådan kulturhistorie måtte også tage stilling til, hvordan vi kan forstå teknologisk og kulturhistorisk forandring i forhold til hinanden.

Netop et sådant elektrisk kapitel ville kunne trække på allerede eksisterende dansk forskning. En gruppe er de første behandlinger af Danmarks eller danske 
byers elektrificering som samlet fænomen, typisk skrevet af ingeniører med tilknytning til udviklingen. ${ }^{4}$ I feltet mellem kultur- og teknologihistorie er der også skrevet fremstillinger af elektricitetens historie, bl.a. med fokus på betydningen for det moderne hjem, for en række industrielle virksomheder og innovatorer og for dansk historie og byhistorie, ligesom der i 1991 kom et oversigtsværk med kulturhistorisk perspektiv. ${ }^{5}$ Man kunne knytte dette perspektiv sammen med forskning hos andre danske historikere, som åbner feltet på tværs af videnskabs-, teknologi- og kulturhistorie, i hvilket der er reelle nye opdagelser at gøre for kulturstudier i bred forstand. ${ }^{6}$ Den periode omkring 1880-1914, hvor de større danske byer elektrificeres, er præget af ændringer på flere felter, som ikke kun er samtidige, men som til dels gensidigt konstituerer hinanden. Industrien og det offentlige rum i bred forstand elektrificeres, samtidig med at man udvikler et sprog omkring elektriciteten, der spreder sig i skøn- og faglitteratur. Nye sociale og professionelle grupper, særligt ingeniørerne, men også psykiaterne eksempelvis, indtager og udvikler dette sprog samtidig med at de bruger og udvikler elektricitetens tekniske mulighedsfelt. Endelig bliver hverdagslivet i byen påvirket på forskellig vis, og byens brugeres kroppe indgår i disse forandringer, idet folk bl.a. opfinder og tilpasser praksis efter sporvognen og den nye belysning.

\section{Forbundne kar}

I januar 1900 talte major L. Ernst til Den Tekniske Forenings møde under titlen "Forskellige Fremskridt og Nyheder paa Elektricitetens område". ${ }^{7}$ Her fremhævede han den nye udvikling hen imod en trådløs telegraf og den elektriske belysning. Ernst fremhævede dr. Auer, der eksperimenterede med det sjældne metal Osmium, der ophedet i vakuum giver et kraftigt lys. En anden vigtig udvikling for tidens nye teknologi var overgangen fra 110 til 220 volts standard i de elektriske systemer. ${ }^{8}$ Det næste vigtige fremskridt, Ernst nævnte, var de elektriske sporveje. Overledningssystemet gjorde sporvognen til del af et elektrisk kredsløb, hvor strømmen går ned gennem kørestangen, passerer elektromotoren i vognen, og går gennem hjulene og skinnerne tilbage til stationen. Ernst advarede mod den

4 Dahl, Faaborg-Andersen og Gelardi, 1939; Faaborg-Andersen, 1942; Gelardi, 1940; Böcher, 1945; Rode (red.), 1942.

5 Olesen and Thorndahl, 2004; Wistoft, 1994; Wistoft oa., 1992; Buhl, 2005; Hyldtoft, 1984; Jensen og Schmidt, 1982.

6 Uden at forsøge at være dækkende kan man pege på forskning i dette felt, som f.eks. Simonsen, 2008; Wagner og Bruhéze, 2012; Buhl og Nielsen, 1994; Nye, 1992; Møller, 2002; Wistoft og Nielsen, 1998.

7 Den Tekniske Forenings Tidsskrift, 1900, s. $29 \mathrm{ff}$.

8 Netop denne teknologi skulle blive udviklet af danskeren Valdemar Poulsen, som flere gange indstilledes til Nobelprisen for arbejdet med sin buesender. 
"vagabonderende strøm” som forstyrrede fintmålende apparater i nærheden og eroderede det metal den måtte finde som ledere undervejs.

Den udvikling, hvis seneste nyheder Ernst her refererede, var den omfattende elektrificering af det københavnske bysamfund. Elektriciteten havde spredt sig i byerne, og de teknologier, der var afledt af den, som kommunikation, lys og offentlig transport, var tidens store netværksprojekter, både for private firmaer som det ny KTAS med C. F. Tietgen i spidsen, men også for Københavns Borgerrepræsentation. I 1891 anlagdes landets første elværk i Køge, og et par måneder senere i større omfang i Odense. Året efter kom København med og anlagde elværket i Gothersgade, der forsynede kvarteret omkring Kongens Nytorv. Omkring 1900 var der fire elektricitetsværker i København og syv i købstæderne udover de private værker, der forsynede fabrikker og større gårde. Udviklingen tog fart i perioden fra 1900 og de følgende år. ${ }^{9}$ Det elektriske netværk eller system er defineret af teknologihistorikeren Thomas Hughes, som et sæt af relationer mellem heterogene komponenter, der gennemløber en række faser i sin udvikling. ${ }^{10} \mathrm{En}$ af Hughes' fortjenester er, at åbne netværksbegrebet for sociale og teknologiske komponenter og dermed belyse kulturelle aspekter af de store teknologiske systemer. På den anden side er der også hos Hughes et fokus på, at systemer bevæger sig mod et i forvejen defineret mål, en determinisme man bl.a. kan spore i hans idé om "reverse salients".

Elektrificeringen var en international tendens, som voksede frem i europæiske og amerikanske byer, store som små. David Nye beskriver den indledende modtagelse af elektriciteten i de amerikanske metropoler og landdistrikter, fra New York til Muncie, Indiana, som en begejstring med nærmest overjordiske perspektiver. Den menneskelige organisme blev beskrevet som elektrisk, og elektriske eliksirer blev solgt. I mindre, rurale bysamfund udbredtes også hurtigt elektrisk lys, om end med meget besværlige opstartsforhold. Men New York var med bl.a. det første offentlige elværk hurtigt til at tilegne sig den elektriske strøm. ${ }^{11}$ Nyes overordnede konklusion er, at elektrificeringen af de amerikanske byer har en dobbelt konsekvens - en styrkelse af centrumdannelsen i større byer og en decentralisering af hjemmet. Denne dobbelthed, skriver Nye, gjorde elektricitetens betydning mindre klar end bilens, hvilket slår igennem i den større historiografi omkring bilismen, som den store transformator af den moderne by. ${ }^{12}$

Berlin kandiderede også til positionen som den førende Elektropolis, men her som ny hovedstad i konkurrence med andre tyske byer i et nyt, ambitiøst kejser-

9 Rode (red.), 1942; Dahl, Faaborg-Andersen og Gelardi, 1939; Faaborg-Andersen, 1942, s. 42.

10 Hughes, 1983 , s. $5 \mathrm{ff}$.

11 Offentligt bruges her om det at levere strøm til offentligheden. Værket var privat ejet og bygget af Edisons firma.

12 Nye 1992, s. 384. 
rige der var ambivalent i forhold til teknologisk ekspansion. ${ }^{13}$ Berlins bystyre etablerede et monopol med det tyske Edison-selskab, som koncessioneret virksomhed på området. Først åbnede en blokstation - dvs. en enkelt karré med eget elværk - og så i 1885 den første centralstation i Markgrafenstrasse. Sammen med Siemens, der også var etableret i Berlin, dominerede AEG teknologioverførslen til Danmark, indtil vekselstrømssystemet blev en konkurrent sidst i 1880'erne. ${ }^{14}$ Særligt Berlins industrielle udstilling i 1896 markerer byen som en elektrisk centrum, men den tegner også et kort over de indre positioner i forhold til den elektriske teknologi. Her er det industriborgerskabet og ingeniørstanden der gennemfører udstillingen på trods af modstand fra kejseren. Mange andre byer indgik i konkurrencen, bl.a. Paris og Wien med sine store, elektriske udstillinger i 1880'erne, der blev fulgt nøje i København. ${ }^{15}$

Ligesom i mange andre storbyer i denne periode blev elektriciteten også i København knyttet til det moderne og til en omkalfatring af det offentlige rum. Hovedstaden var ikke først med at bruge ny teknologi men var størst og etablerede nogle omfattende offentlige systemer som i f.eks. Birmingham, Glasgow og Wien. ${ }^{16}$ Her var også det, teknologihistorikeren Hans Buhl kalder et "teknologisk støttenetværk" - ingeniører, elektroteknikere og teknokrater - som kunne håndtere mere specialiserede systemer. Ifølge Buhl, var det elektrotekniske miljø i Danmark omkring 1900 ikke specielt innovativt og ikke præget af større udviklingsafdelinger eller -institutioner. Der var på det tidspunkt ikke en udviklet uddannelse af elektroingeniører, og det meste teknologi blev importeret. På den baggrund skiller København sig ud. Der var grøde i den elektrotekniske industri, blandt andet på grund af den generelle industrielle vækst og en række større elektriske virksomheder lå i København. Enkelte opfindere som Valdemar Poulsen tog relativt store skridt, og det københavnske miljø var mere teknologisk indstillet. Desuden blev elektriciteten en vigtig politisk sag for byens styre på tværs af partiskel. ${ }^{17}$ Endelig peger Michael Wagner på uddannelsen af elektroingeniører fra 1903 som en nyskabelse.18

\section{Systemkrig?}

Et afgørende projekt for København i perioden var udrulningen af et elektrisk jævnstrømsnetværk. 1890’erne var årtiet for den såkaldte ”systemkrig” i Europa

13 Se f.eks. Levin 2010, s. 193 om kejser Vilhelms ambivalens vis-a-vis industriel teknologi.

14 Wistoft 1994, s. 162.

15 De internationale udstillinger blev fulgt detaljeret i tidsskrifter som Den Tekniske Forenings Tidsskrift, Tidsskrift for Physik og Chemi, Elektroteknikeren og Industri-Tidenden.

16 Hård og Misa (red.), 2008, s. 1-22.

17 Böcher, 1945; Buhl og Nielsen, 1994, s. 62; Buhl, 2005.

18 Harnow, 2011. 
og USA mellem jævn- og vekselstrøm, og her valgte bystyret Thomas Edisons jævnstrømssystem som en pragmatisk løsning frem for den stærke vekselstrøm. ${ }^{19}$ Man kan diskutere, i hvor høj grad denne krig kunne udspille sig under danske forhold, idet man indtil efter 1900 ikke reelt havde den viden, der skulle til. Desuden indskrev jævnstrømmen sig i en særlig kulturel udvikling, idet den var ideel til brug for den voksende andelsbevægelses elværker, der havde et mindre opland og kunne drives med færre anlægsudgifter. Omkring 1900 var der således omkring 400 små jævnstrømsværker fordelt i landdistrikterne. Dette var jo ikke en urban udvikling men var med til at gøre elektriciteten til et større, nationalt spørgsmål. I Danmark nedsattes Elektricitetskommissionen i 1904 for at diskutere eventuelle anlæg af stærkstrømsanlæg. Kommissionen barslede med en betænkning i 1906, der mundede ud i en lov i 1907. Som konsekvens anlagde man det store H. C. Ørstedsværk i den vestlige del af byens havn.

Men som sagt gik København først ind på et jævnstrømsspor. I Borgerrepræsentationen var man først tilbageholdende. Man diskuterede elektrisk gadelys allerede i 1870'erne, men diskussionen blev lukket og åbnet flere gange i løbet af 80'erne, ikke mindst fordi man var bange for at skulle konkurrere med det dyre gasnetværk. ${ }^{20}$ Ingeniør Georg Howitz var en ledende figur i etableringsfasen af gasværkssystemet. Han var forbeholden, da man i 1884 fik et andragende om drift af et elektricitetsværk i byen. Byen var netop i gang med opbygningen af et bekosteligt gassystem, og man mente ikke, der var plads til to energisystemer side om side. Indtil 1891 var billedet spredt. Der fandtes en række private elværker, typisk til fabrikker, og fra 1891 - 1905 blev opført ca. 30 private værker i byen. ${ }^{21}$ De forsynede enkelte karréer eller blokke - de såkaldte blokstationer - og pressede processen ved at udfordre muligheden for et sammenhængende netværk. Rode nævner, at der omkring 1890 fandtes blokstationer flere steder i byen, bl.a. på Nørrebrogade og Købmagergade, men særligt i rådhuspladsområdet, som f.eks. på Nørregade, Vestergade samt det store Dagmar-anlæg, der forsynede 150 glødelamper med strøm. ${ }^{22}$

Det elektriske netværk var desuden en mere kompliceret opgave for byen end gasnetværket havde været. Julius Thomsen formulerer det på følgende måde i Borgerrepræsentationen:

Den der staaer i Spidsen for eet elektrisk Belysningsanlæg maa nemlig være udrustet med specielle Kundskaber i mathematisk og physisk Retning, da den elektriske Belysning hviler paa et fuldstændigt videnskabeligt Grundlag, og forudsætter Beregninger, der maa udføres med den største 
Sikkerhed, medens Gasværksdriften væsentlig er en Industri, hvis Ledelse i al Fald ikke i samme Grad gør Krav på mathematiske kundskaber. ${ }^{23}$

Det var altså en anden netværksteknologi-viden, der var på spil, og dermed også en anden opgave for bystyret. Den nye stadsingeniør Charles Ambt tog på studierejse til England. Kommunens elektriske ingeniør Ib Windfeldt-Hansen rejste rundt på kontinentet i begyndelsen af 1889 for at studere de byer, der havde taget skridt til elektrificering. Ambt og Windfeldt-Hansen interesserede sig i deres rapporter og rejsenoter for tekniske forhold som spændingstype og ledningsnet. Men de interesserede sig i lige så høj grad for organisation og finansiering, dvs. koncessioner, selskabstyper, driftsansvar osv. Winfeldt-Hansen vendte hjem med en rapport, der stærkt anbefalede et jævnstrømssystem, som beboerne kunne abonnere på.

Det afgjorde sagen. Borgmester Øllgaard fremlagde et projekt til 14.000 lamper og 1,4 mio. kr., og i september 1889 besluttede man oprettelse af en station. I marts 1890 udsendtes indbydelser til abonnementstegning, og den første succes var overvældende. Allerede inden det første spadestik udvidede man derfor til 20.000 lampers kapacitet. ${ }^{24}$ Man anlagde elværket nær Kgs. Nytorv, da man kunne se, at det var i dette kvarter, der var størst interesse for gasnettet i sin tid.

Den 5. oktober 1900 blev det vedtaget at oprette Elektricitetsværkernes Ingeniørkontor. ${ }^{25}$ Kontoret tog sig af al drift af ledningsnet, gadebelysning, stik og målerledninger, tilsyn samt den elektriske del af sporvejene. Hermed blev byens første netværksteknologiske specialenhed oprettet. I 1894 begyndte man projekteringen af værk nummer to, Vestre Elværk, da Gothersgadeværket ikke kunne dække behovet på Vesterbro og den nye Rådhusplads. Man placerede det på den nuværende Tietgensgade, nær de store forbrugere som havnen (der også kunne levere kølevand til værket), Tivoli og Rådhuspladsen. Det var i konstruktionen ligesom Gothersgade, og kørte på koks og kokssmuld. I år 1900 begyndte man opførslen af Østre Elværk på Østerbro, og disse tre værkers kapacitet dækkede til sammen byens behov indtil 1917. ${ }^{26}$

\section{Nerverne som netværk af energi}

Da først et elværk var etableret og processen begyndt, fik det betydning for etableringen af en række andre netværk i byen, både som konsekvenser og forudsætninger for det videre forløb. Vi kan altså i disse nedslag se, hvordan der over en kort 
periode bliver etableret et stort teknologisk system med en række "parasitiske" netværk, som lever af det og er mere eller mindre sammenvævet med det. Det skal vi vende tilbage til længere fremme for her kort at introducere et andet rum, hvor elektrificeringen af byen foregår samtidigt og forbundet med den ovenstående, men med nogle helt andre konsekvenser, nemlig i skønlitteraturen og den populærmedicinske faglitteratur.

I Johannes Jørgensens bog ”København” fra 1892 optræder det offentlige rums lys på alle niveauer: de elektriske lamper, der hænger som måner over jernbaneterrænet, de elektriske lysballoner foran butiksvinduerne, glasboblerne på Kongens Nytorv. ${ }^{27}$ I det hele taget giver det elektriske lys' voksende tilstedeværelse i det offentlige rum anledning til en række reaktioner og refleksioner hos københavnske forfattere. Et kompleks, der var særligt intenst i den litterære diskurs lige omkring 1900, var forholdet mellem den teknologiske by og den medicinske krop - det var klimakset for "nervernes århundrede” og "nervernes diskurs”. Bekymringen for byens hastighed, flygtighed og overophedning af sanseapparatet, som også findes hos de klassiske tyske sociologer, var temaet for en række bøger som Ludvig Feilbergs Om størst udbytte af sjælsevner (1881), Knud Pontoppidans Neurasthenien (1886), Carl Langes Bidrag til Nydelsernes Fysiologi (1899), Daniel Jacobsons Nervøsitet og andre nervesygdomme (1902) og Frode Sadolins Nerve-Helse (1908). ${ }^{28}$

Disse forfattere identificerede sygdommen Neurasteni eller nervesvækkelse som konsekvens af overstimuleringen eller -opladningen, og anbefalede ophold på kursteder eller i landlige omgivelser for at aflade og genvinde balancen. Axel Garde beskriver, hvordan det "elektriske Uvejr" af nerveirritationer pressede byboeren til flugt og aggression. ${ }^{29}$ Diagnosens symptomer er som at se en direkte oversættelse af de kendetegn, som den daværende sociologiske outsider Georg Simmel i netop de år fremførte i en forelæsning på den store byudstilling i Dresden i 1903. Senere skulle Simmels tekst oversat til engelsk "The Metropolis and Mental Life" blive en klassisk tekst både i sociologi og bystudier. Bedre end andre samtidige beskrev Simmel sammenhængen mellem det psykologiske overload på den ene side, og byrummets flimrende sammensætning af tilfældige møder, udvekslinger og flydende værditilskrivninger på den anden. Den moderne by, sagde Simmel, belastede og opbrugte menneskets opmærksomhed..$^{30}$

Simmels bekymring for det moderne og den direkte sammenbinding af krop og byrum lå i tiden. Hvis vi prøver at kigge nærmere på en af de nævnte danske psykiatriske bøger, Pontoppidans "Neurastenien”, ser vi allerede på en af de første sider denne formulering: 
thi vor Hovedstad er netop nu naaet op til at blive en stor By, hvor den complicerede og potenserede Tilværelse er Udtryk for et overinciteret Nervesystem. ${ }^{31}$

Pontoppidan skelner her ikke klart mellem nervesystemet som en metafor for byen eller for kroppen. Det er som om begge dele er komplicerede, potenserede og overinciterede, og filtret ind i hinanden i den moderne verdens sansebombardement. Denne sammenfiltring er gennemgående i Pontopiddans bog, ligesom den er det i en række afhandlinger fra europæiske og amerikanske neurologer og psykiatere i perioden. I den internationale diskussion samler synspunkterne sig omkring New York-psykiateren Beard, der opfandt begrebet ”Neurasteni”, og franske psykiatere som Achille-Adrien Proust, far til den senere berømte forfatter Marcel, der selv havde denne diagnose. Beard så neurastenien som en særlig amerikansk sygdom knyttet til Den Nye Verdens påtrængende modernitet, og behandlede den bl.a. med elektroniske stød. Europæiske psykiatere overtog hans diagnose men ikke hans behandling. Franskmændene mente, den nervesvækkede tilstand var arvelig og knyttet til den "neuropatiske familie" af sygdomme, bl.a. kendetegnet ved en konstant trang til bevægelse. Der var også aspekter af racetænkning i diskussionen. Lægen Phillipe Thissiet introducerede i 1887 historien om "Den Vandrende Jøde”, der er tvunget til at gå rastløst om indtil dommedag, i den medicinske terminologi som billede på sygdommen. ${ }^{32}$

Proust udgav i 1897 bogen "Neurastheniens hygiejne”, som blev meget udbredt i Frankrig, med livagtige beskrivelser hentet fra hans søn, der kunne tilbringe mere end 6 dage i sengen om ugen, hvor han skrev på et stort litterært værk om livet i det franske borgerskab. Adrien Proust pegede på storbyens borgerlige elite og "hjernearbejderne" blandt disse som lokus for neurastenien - den samme gruppe som samtidig var kernepublikum i Sigmund Freuds psykoanalytiske klinik i Wien. Freud og Proust havde diskuteret fænomenet, og førstnævnte arbejdede videre med neurastenien som en neurose, der til forskel fra den hysteriske patients "perverterede vilje" udviste en "udtømt vilje".

\section{Den urbane krop sammenføjes}

Tilbage hos Pontoppidan i København kan vi genfinde den internationale diskussion. Som Beard mener Pontoppidan, at neurastenien som lidelse, er knyttet til den urbane modernitet, men som den franske skole mener han ikke, den begrænser sig til den Nye Verden. Som Proust knytter han sygdommen til den særlige 
gruppe på fremmarch i det elektrificerede bysamfund. Pontoppidan kalder dem "mellemklassen":

Den Klasse derimod, for hvilken den nervøse Elendighed i særlig Grad er Tidens Ulykke, det er den saakaldte dannede Mellemklasse, det er dem, der i Kampen for Tilværelsen repræsentere de Kæmpende, de Saarede og de Slagne, det er den Fattigdom med Pretentioner, til hvilken de fleste af os høre, vi, som økonomisk talt ere Proletarer, men som dog fordre Deelagtighed i de Høiere sociale Nydelser. ${ }^{33}$

Spændt ud mellem den moderne bys to poler, den uambitiøse arbejderklasse og det velbjærgede bedsteborgerskab, er middelklassen, ifølge Pontoppidan, i fare for at blive overopladt. Og denne opladning er ikke kun en psykologisk tilstand: Pontoppidan udbreder den nervesvækkede tilstand som et fænomen, der gennemtrænger den moderne bykultur: trafik, turisme, byens boliger, onani, homoseksualitet, den borgerlige kvindes selskabsliv - allehånde praksisser knyttet til den moderne by og krop ses som nervesvækkede. ${ }^{34}$

Der er en række sådanne sygdomme, der knyttes til byen i denne periode - agorafobi, klaustrofobi osv. - men neurastenien er særligt dominerende og fungerer hos nogle kommentatorer som overordnet diagnose for de andre. Det interessante er her, at tilstanden med Beards "genopdagelse" eller navngivning knyttes direkte til elektriciteten, som Jes Fabricius Møller understreger i sin PhDafhandling. ${ }^{35}$ Beards genopdagelse kan, som Møller antyder, knyttes til et større skift i forholdet mellem krop og psyke. Følelseslivet, som i romantikken var knyttet til immateriel ånd, fik en potentiel forbindelse med den nye, biologiske krop, der voksede ud af 1800-tallets naturvidenskab. Som kulturhistorikere har peget på, var der også i 1800-tallets Danmark en bølge af følsomhed knyttet til bl.a. det nationale, og med nervøsiteten kommer altså et forbindelsesled mellem følelse og fysiologi. ${ }^{36}$ Som en yderligere twist i de overlappende felter kommer termodynamikken og den elektriske ledning ind, som frugtbare figurer for at forstå den moderne affekt og følelses anatomi. Det giver mulighed for helt nye analogier mellem den maskinelle krop, dens energier, affekt og følelse.

Her bliver elektriciteten nøgle til et sprog, der kobler tekno-, bio- og psykologi på en ny måde, som hos ingeniøren Ludvig Feilberg, der beskrev det offentlige rum med elektrisk inspirerede begreber som "Kredsning” og "Ligeløb” som et sted, hvor folk dør unge på grund af det voldsomme krav om opmærksomhed fra "ting” i byen, som f.eks. de elektriske sporvogne. Feilberg var inspireret af

33 Pontoppidan, 1886, s. 5.

34 Pontoppidan, 1886, s. $7 \mathrm{ff}$.

35 Møller, 2002, s. $146 f f$.

36 Møller, 2002, s. 81. 
elektroteknikken og telegrafien, og af maskinen som metafor for kroppen såvel som byen. ${ }^{37}$

Så kroppens og byens opladte rum er svære at adskille i det elektrificerede København. Som vi har set, producerer elektriciteten en opmærksomhed omkring energi, cirkulation og kraft: man bliver stimuleret, inciteret, overfølsom. En anden side af denne kulturelle elektrificering er kommunikationen. Fra og med telegrafens opfindelse havde elektriciteten stået for en næsten tidløs overførsel af information mellem byer og nationer hjulpet på vej af netværk og apparater af forskellig slags. Dette kommunikative potentiale, forbundet med de materielle apparater og netværk, bliver også en del af denne sammenvævning. Den italienske neurolog, antropolog og forfatter Paolo Mantegazza blev i denne periode oversat til dansk, og hos ham ser man det tydeligt. Den nervøse bybeboer har, siger Mantegazza,

femhundrede, ja femtusinde [sanser], og hans Nerver, som er blevne til lutter Mikroskoper, Teleskoper, Mikrofoner, Telefoner og Galvanometre holder ham i bestandig Uro og forvandle ham til et Spejl med mange hundrede Flader, som optager Alt, hvad der rører sig opadtil og nedadtil, i Højden og i Dybden ${ }^{38}$

Stimuleringen af kroppen gør den hypersensitiv og registrerende, den "optager” alt, registrerer byens mangfoldige tegn og meddelelser. En af de forfattere, der er hurtig til at optage denne krop i sit sprog, er Herman Bang:

Og som om hendes Tanker, der syntes at have selve Dødsmomentets sprængende Voldsomhed, havde meddelt sig til ham ved tusind elektriske Traade paa en Gang, gennemløb han dem alle og forstod hende. ${ }^{39}$

Udover at være en energiform, der driver eller "inciterer”, er elektriciteten altså også ensbetydende med et kommunikationsnetværk, der formidler meddelelser så lynhurtigt, at det virker samtidigt eller som her i Bangs "Stuk" næsten telepatisk. Kroppen besad sin egen elektricitet, der som vi har set kunne påvirkes af byrummet, såvel som gennem forskellige former for terapi, blandt andet i Beards nervebehandling. ${ }^{40}$ Impulser og information kunne løbe gennem kroppen og påvirke den gennem kredsløb og knudepunkter, ligesom de større, elektriske netværk, der kom til at gennemløbe de voksende byer i perioden.

37 Feilberg, 1881.

38 Mantegazza, 1888 , s. 87.

39 Bang, 1887, s. 180.

40 Der er en række andre elektriske behandlingsmetoder af kroppen som er undersøgt kulturhistorisk, bl.a. Herzig, 2008; Nye, 1992, s. 5 ff. 


\section{Den elektriske by}

Netop byens elektriske netværk kunne være et stærkt billede på den elektrificerede krop, med hvilken de også var tæt forbundne. Typisk forbindes de med den nye tids opskruede tempo, hvor byrum og krop er som forbundne kar. Som her i en forelæsning af Peter Panum fra 1904:

Medens 'i gamle Dage' Folk 'tog den med Ro', og Livet gled stille og fredeligt hen for flittige og paapasselige Mennesker, er Livet i Nutiden med dens Jernbaner, Cycler, Telegraf og Telefon en uafbrudt Kamp for Tilværelsen, den Ene spænder Ben for den Anden, Ingen har Tid til at Vente, der maa stadigt arbejdes med fuld Kraft. ${ }^{41}$

Den svenske forfatter Walther Ljungquist beskriver dette med en kobling nervemetaforen og en særlig, vægtløs følelse:

A railway junction is like a knot of nerves, it vibrates with life. All roads lead to here. Here we are all thrown together, share a few moments and hasten on ... you move with a feeling of weightlessness, a feeling of being propelled forward..$^{42}$

En væsentlig del af disse netværk, som gennemtrængte byen og skabte stress og vægtløshed var elektriske. Drevet af de nye københavnske elværker opstod en række andre, mere eller mindre afhængige systemer - dem jeg i begyndelsen kaldte de "parasitiske" netværk. Mens det elektriske ledningsnet spredte sig i København fra knudepunkter på Kongens Nytorv og Rådhuspladsen, dannede det platform og matrice for andre elektrificerede teknologier. Hvis man således kortlagde spredningen, ville man se, hvordan transport, lys og kommunikation udviklede sig enten som slyngplanter langs elnettets linjeføringer, eller som knopskydninger på dette, med egne linjer fra elværker eller knudepunkter.

Byen er altså et rum, der fra 1880'erne gradvist bliver gennemtrængt af den elektriske energi og kommunikation. Dette sker, som teknologihistorikere har peget på, i spring fra "øer” af netværk til transurbane, -regionale, -nationale sammenkoblinger. ${ }^{43}$ Mens den nationale og globale udvikling mestendels foregår i mellem- og efterkrigstiden, kan vi se, hvordan elektriske netværk omkring 1900 udvides, tilkobles og vokser sammen i København indenfor rammerne af byen

41 Panum, 1904, s. 490. Citeret hos Møller, 2002, s. 164.

42 Ljungquist, 1933. Citeret i oversættelse Löfgren, 2008, s. 341.

43 Graham og Marvin, 2001, s. 41; Schott, 2010. 
og delvist det nationale territorium. ${ }^{44}$ Et af de tidlige systemer, telegrafen, kan bruges som eksempel på sådanne sammenvoksninger. Brandvæsenet opbyggede allerede fra 1870'erne telegrafiske forbindelser på tværs af byen, og 1879-81 nedlagdes brandtelegrafkabler i støbte rør under byen. ${ }^{45}$ I 1871 fik brandinspektøren en linje til privatboligen, året efter blev der trukket en til vandværket, og i begyndelsen af 1880'erne blev der ført linjer til vigtige bygninger som Nationalbanken, Hovedpostkontoret og Nationalmuseet. Omkring 1900 var systemet udvidet og udviklet, og alarmer gik dels til den lokale brandstation, men samtidig til hovedstationen. Der var altså en dobbelt sikring i systemet, og når ilden var opdaget og lokaliseret, var udrykningen hurtig. I 1891 holdt brandchefen Sextus Meyer et foredrag i Industriforeningen, hvor han på forespørgsel fra foreningens formand og til publikums jubel tilkaldte sprøjtevognene med kort varsel. ${ }^{46}$

Udrykningen var altså forbedret. Men det var stadig et problem for brandfolkene at få lokaliseret ilden hurtigt nok. Samtidig kunne man se en fordel i at centralisere brandvæsenet. Mindre stationer nedlagdes, og brandtelegrafen omlagdes. Der opstilledes brandskabe i den indre by, hvor almindelige forbipasserende kunne slå alarm ved at trykke på en knap. ${ }^{47}$

...øjeblikkeligt sætter et Telegrafapparat på den nærmeste Brandstation sig i Bevægelse, der gives signal til Mandskabet at det skal rykke ud, og ... højst 10 minutter efter Ildens Opdagelse er Sprøjter og Stiger og Officerer paa Stedet...Naturligvis ere de moderne Opfindelser, Telegraf og Telefon, benyttede efter den størst mulige Maalestok. Paa Hovedbrandstationen findes saaledes et helt, stort Værelse udelukkende optaget af elektriske Apparater. ${ }^{48}$

Brandtelegrafen hvilede altså dels på centraliseret information og en decentral brug af det "offentlige øje" i sit behov for konstant at optimere reaktionshastigheden. Nettet udviklede sig ved siden af andre telegrafnet som Statstelegrafen og kommercielle forbindelser men optages gradvist i det offentlige net for til sidst at blive overtaget næsten helt af telefonforbindelser, der er hurtigere og mere fleksible. ${ }^{49}$

Mens telegrafen således med tiden blev en del af - og integreret i - telefonnettet, var byens gadebelysning et eksempel på et netværk, der var direkte afhængigt af det kommunale elværkssystem. I 1881 ophængtes en buelampe foran National

44 Globale, danske projekter som Store Nordiskes kabelføring er på grænsen men er ekstraordinære i denne periode, Wistoft, 1994; Wistoft oa. 1992.

45 Hassø, 1931, s. 402.

46 Salmonsens Konversationsleksikon, "Brandtelegraf” J. H. Schultz, 1930, s. 860.

47 Hassø, 1931, s. 483.

48 Illustreret Tidende nr. 44, 1903.

49 Hassø, 1931; J. H. Schultz, 1930. 
Scala ved Tivoli for at lokke publikum til. Det skarpe hvide lys faldt på pladsen ved forlystelseskomplekset et par hundrede meter vest for Rådhuspladsen, og satte dermed en scene for lyset som en spektakulær nyhed i byens rum. ${ }^{50}$ Igen året efter holdt samme etablissement en elektrisk lysfestival med forskellige typer belysning inde og ude. ${ }^{51}$

Med det elektriske lys skete en rumliggørelse, som i høj grad senere er blevet taget for givet, og som Kulturgeografen Nigel Thrift kalder "This history of everexpanding landscape of light which we now take for granted". ${ }^{52}$ Thrift peger på en række ændringer i rumligheden omkring det elektriske lys: Dels en "kolonisering af natten", hvor nye praksisser rykker ind i byen efter solnedgang. Byen havde længe været ramme om natlige aktiviteter, men med det elektriske lys blev de flere og mere mangfoldige. Natten blev ramme om underholdning, offentlige fester og særlige forbrugsformer, mens tidligere tiders bekymring for sikkerheden i mørket mindskedes. Det elektriske lys gav også momentum til konstruktionen af de "drømmerum”, som bl.a. Walter Benjamin senere blev så fascineret af stormagasiner, hoteller, caféer, passager - hvor lyset inviterer til konsumption og selvforglemmelse. ${ }^{53}$ Som David Nye skriver: "spectacular lighting ... quickly became a central cultural practice.${ }^{54}$ Lyset medførte også nye overvågningsmuligheder i fabrikker, fængsler og på offentlige gader og pladser. Dette var ikke for alle en positiv ting, og skodder, spejlglas og belysningens blandede modtagelse i nattelivet fortæller om en kulturel "balancering” af det gennemtrængende lys i stedet for den konstante søgen efter mere lys, som nogle kulturhistorikere forudsætter. ${ }^{55}$ For eksempel fik dansesalonen Figaro i 1884 kulbuelys men måtte tage det ned igen efter klager fra det kvindelige klientel, der ikke holdt af den skarpe belysning. ${ }^{56}$ Det skal nævnes her, at byen havde haft gasbelysning siden midten af 1800-tallet, som også fortsatte i lang tid sideløbende med elbelysningen. Gaslampernes lys havde en stor betydning for bl.a. fornemmelsen af sikkerhed og orientering, men det lyslandskab som antydes ovenfor blev først tilstedeværende med det stærke, hvide elektriske lys.

I 1870'erne begyndte man at diskutere elektrisk belysning i de københavnske gader. Et af de første temaer var den sikkerhed mod overfald og trafikulykker, som de stærkere kulbuelamper angiveligt ydede i forhold til gaslamperne. På det tidspunkt var det elektriske lys dog ikke et realistisk alternativ til gaslamperne,

50 Dahl, Faaborg-Andersen og Gelardi 1939, s. 482.

51 F.eks. Wistoft, 1994, s. 163. Kulbuelampen havde været forevist offentligt i 1857 på Christiansborg Ridebane.

52 Thrift, 1996, s. 268.

53 Williams, 1982; Highmore, 2002.

54 Nye, 1992, s. 383.

55 Highmore, 2005; Schivelbusch, 1995; Dahl, Faaborg-Andersen og Gelardi, 1939; Dennis, 2008; Otter, 2010). Gadelysets materielle betydning er også undersøgt hos Otter, 2008.

56 Hansen, 1992, 11; Dahl, Faaborg-Andersen og Gelardi 1939, s. 481. 
og man havde i 1885 afvist en henvendelse fra et privat firma om drift af en elektrisk station. ${ }^{57}$ Med anlæggelsen af Gothersgadestationen kunne belysningsnettet dog tage sit første skridt. Det første gadelys tændtes på Kgs. Nytorv d. 26. maj 1892 i anledning af Christian IX’s guldbryllup. I de følgende år fulgte i nævnte rækkefølge Østergade, Amagertorv, Købmagergade, Frederiksberggade, Frederiksborggade, Rådhuspladsen og Vesterbros Passage. Således bevægede systemet sig skridt for skridt fra Kgs. Nytorv mod vest og understregede denne linje i byen som den centrale. Herfra spredtes systemet til andre centrale dele af byen. ${ }^{58}$ De byrum, der først betjentes af det kostbare system, havde altså en særlig betydning, primært gennem tætheden af mennesker eller repræsentativ prestige. ${ }^{59}$ Således voksede det elektriske net frem som et spejl af byens socialt-rumlige hierarki.

Den teknologiske udvikling stimuleredes løbende af krav fra trafikudviklingen og den stigende hastighed i gaderne, hvor især sporvognene satte en stigende hastighed. ${ }^{60}$ Eksempelvis undersøgte man ved asfaltering af de første gader, hvor meget lys asfalten reflekterede og dermed blændede trafikanterne. I den tekniske litteratur understregedes også, at gaslampernes lys var beregnet for fodgængere og langsom trafik, mens den øgede hastighed stillede krav om den stærkere elbelysning. I 1889 fik etablissementerne Wivel og Arena egentlige elektriske lysanlæg, mens Tivoli først i 1898 blev tilkoblet strøm fra offentligt forsyningsnet. ${ }^{61}$ Byen var nu kablet, opkoblet og lysende. Strømmen forlenede det urbane landskab med en ny, pulserende sensitivitet. Selve elektriciteten og dens netværk blev objekt for fascination men også for uro og ulykker. ${ }^{62}$ Hele tiden var udviklingen drevet af "de andre storbyer”, primært i Europa, som København nu ville sammenlignes med. ${ }^{63}$ I 1889 under borgerrepræsentationens forhandlinger om anlæg af en elektrisk centralstation opridsede Politiken således følgende:

Det drejer sig her om en Sag, der utvivlsomt ligger Københavnerne stærkt paa Hjærte; i Udlandets Byer har den elektriske Belysning i de sidste Aar gjort saa enorme Fremskridt, i den Grad taget Têten, at vi næsten maa skamme os, naar vi ser, at en Handskebutik paa Østergade, en Guldsmedebutik på Købmagergade, National og et par Lamper i Tivoli snart sagt er ene om at repræsentere Gadernes højeste Oplysning. ${ }^{64}$

57 Wistoft, 1994, s. 164.

58 Dahl, Faaborg-Andersen og Gelardi, 1939, s. 461.

59 Det eksklusive ved det tidlige elektriske lys fremhæves også hos københavnere som Valborg Nielsen, der fortæller, hvordan hun med sin mor opsøger det nye lys i Jorcks Passage, se Stadsarkivets erindringer, nr. 1237, Nielsen, Valborg, p. 4.

60 Holm og Johansen, 1941, s. 169.

61 Dahl, Faaborg-Andersen og Gelardi 1939, s. $485 \mathrm{ff}$.

62 Wistoft et al., 1992, s. 16.

63 Politiken 3. oktober 1887.

64 Politiken 13. september 1889. 
Kritikken gik også på, at de centrale aktører i den tekniske diskussion, som teknikborgmester Øllgaard, belysningschef Howitz og stadsingeniør Ambt, ifølge Politiken ikke så elektrisk lys som et potentiale i det offentlige men kun det private rum. Det skulle vise sig at gå anderledes.

Mens den elektriske kabelføring under byen var et netværk for sig, kan man se de andre, tilsluttede netværk som snylteplanter eller parasitter, der koblede sig op på elværkskablerne - gadebelysning, telefon osv. Men et netværk var en større elektrisk parasit end nogen andre, nemlig de københavnske sporveje. I de to årtier op til 1900, der betød den mest omfattende acceleration af byernes vækst i den vestlige verden, stod sporvognen frem som vokset ud af urbaniseringens problemstillinger. Et offentligt transportsystem med stor kapacitet, robust udstyr, høj frekvens og økonomisk tilgængelighed for flertallet. Det var et "parasitisk" netværk i den forstand, at det brugte stort set alle de andre netværk, der eksisterede på det tidspunkt, som del af sin drift, men særligt udnyttede det elektriciteten.

Efter at byen i 1863 havde fået sin første hestesporvogn, der bl.a. kørte Frederiksbergs borgerskab ind til centrum, blev København over et par årtier en sporvejsby. En række små private firmaer voksede frem, som i 1890'erne blev samlet i et, De Københavnske Sporveje, hvilket muliggjorde, at hele sporvejsnettet kunne blive elektrificeret omkring 1900. På trods af en mildest talt spredt forskning i denne historie om Københavns første, offentlige transportsystem, kan man se, hvordan sporvejene udviklede sig til at blive et transportnetværk, der gennemtrængte byen i lige så høj grad som andre af tidens metropoler. ${ }^{65}$ For eksempel bliver der over to pinsedage i 1903 kørt en lille halv million passagerer rundt i sporvejsnettet, hvilket er relativt mange i en by, hvis befolkning var omkring fire hundrede tusind. ${ }^{66}$

De sporvogne, der bevægede disse mange kroppe rundt i byen, var elektrificerede i mere end en forstand. Dels var de bygget (eller ombygget), så de brugte strømmen som drivkraft med et system udviklet af den amerikansk-tjekkiske ingeniør Frank Sprague. ${ }^{67}$ Som L. Ernst nævnte i sit foredrag, førtes strømmen fra et kabel gennem sporvognens krop og videre ned i skinnerne, hvor den vandrede rundt i byen som den "vagabonderende strøm”, Ernst advarede mod. ${ }^{68}$ Strømmen drev en række funktioner i vognen: Både udvendig og indvendig belysning kørte på el, der var særlige, elektriske bremser, og dørene i de moderne vogne åbnede og lukkede elektrisk. Som én stor, elektrisk sammenføjning kørte nettets godt 600 vogne således rundt i byen og viste sig at være en ganske god forretning, hvilket var medvirkende til, at nettet i 1911 blev gjort rent kommunalt.

65 Thelle 2013, s. 107ff. Af tidligere beskrivelser kan nævnes bl.a. Københavns sporveje, 1963; Røgind, 1913.

66 Thelle 2013, s. 111.

67 Filarski, 2011 ; McKay, 1976.

68 Den Tekniske Forenings Tidsskrift, 1900, p. $29 \mathrm{ff}$. 


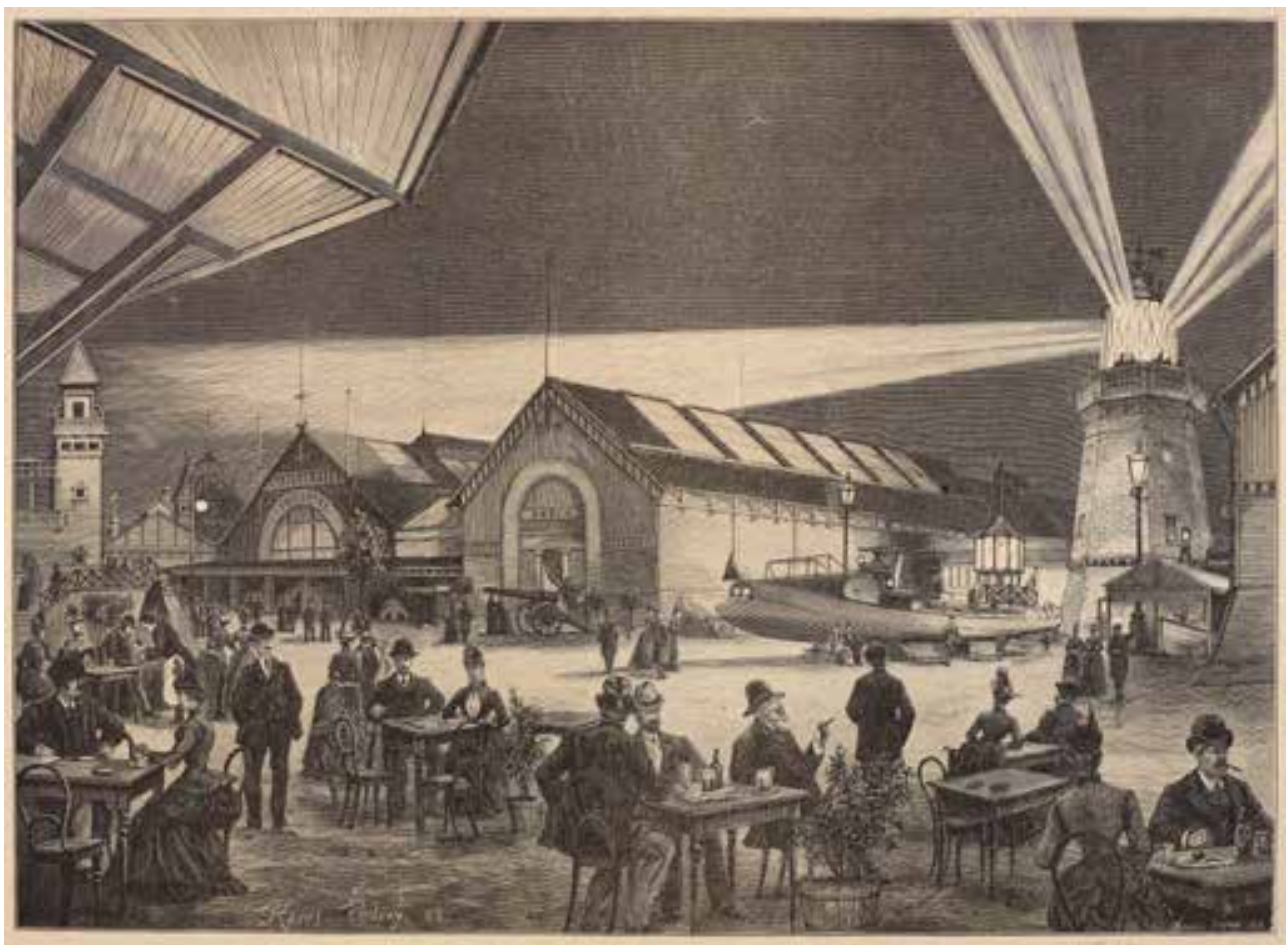

Her er det elektriske fyrtårn både belysning, udstillingsgenstand og orienteringspunkt. Tegning af Karel Sedivy fra den store industriudstilling i København 1888. Det Kongelige Bibliotek.

Sporvejene udviklede sig i et stjerneformet net med centrum i Rådhuspladsen, koblet med ringlinier på tværs, et mønster der stort set fastlagde de ruter, byens busser kører efter i dag. Udviklingen og elektrificeringen af dette netværk betød et nyt byrum præget af forbindelse, tilkobling og navigation. Hvis vi begynder med det første felt, forbindelserne, kan vi passende begynde med eksemplet Linje 1. Den kørte nord-syd mellem Rådhuspladsen og i første omgang Østerbro og siden videre nord til Svanemøllen og Hellerup. ${ }^{69}$ Under navnet "Strandvejslinien" blev den en udflugtsrute for en voksende gruppe københavnere og dermed genstand for livlig diskussion. Et af temaerne var, at linjen blev videreført for langsomt men da den så endelig førtes videre, blev der også protesteret. Som det udtrykkes i Grundejerbladet:

...det staar nu mere og mere klart at de elektriske Sporvogne har fremkaldt en Revolution noget lignende den anden [industrielle] og i Virkeligheden af mindst lige så voldsom Betydning. ... Nogle Forretninger sygne hen, fordi "de elektriske" løbe med deres Kunder, andre Forretninger blomstre fordi Sporvognene bringer dem nye Kunder, for hvem Vejen hidtil var for lang.

69 Denne linie, der var den mest benyttede frem mod 1900, beskrives i Bjørnson, 1988. 


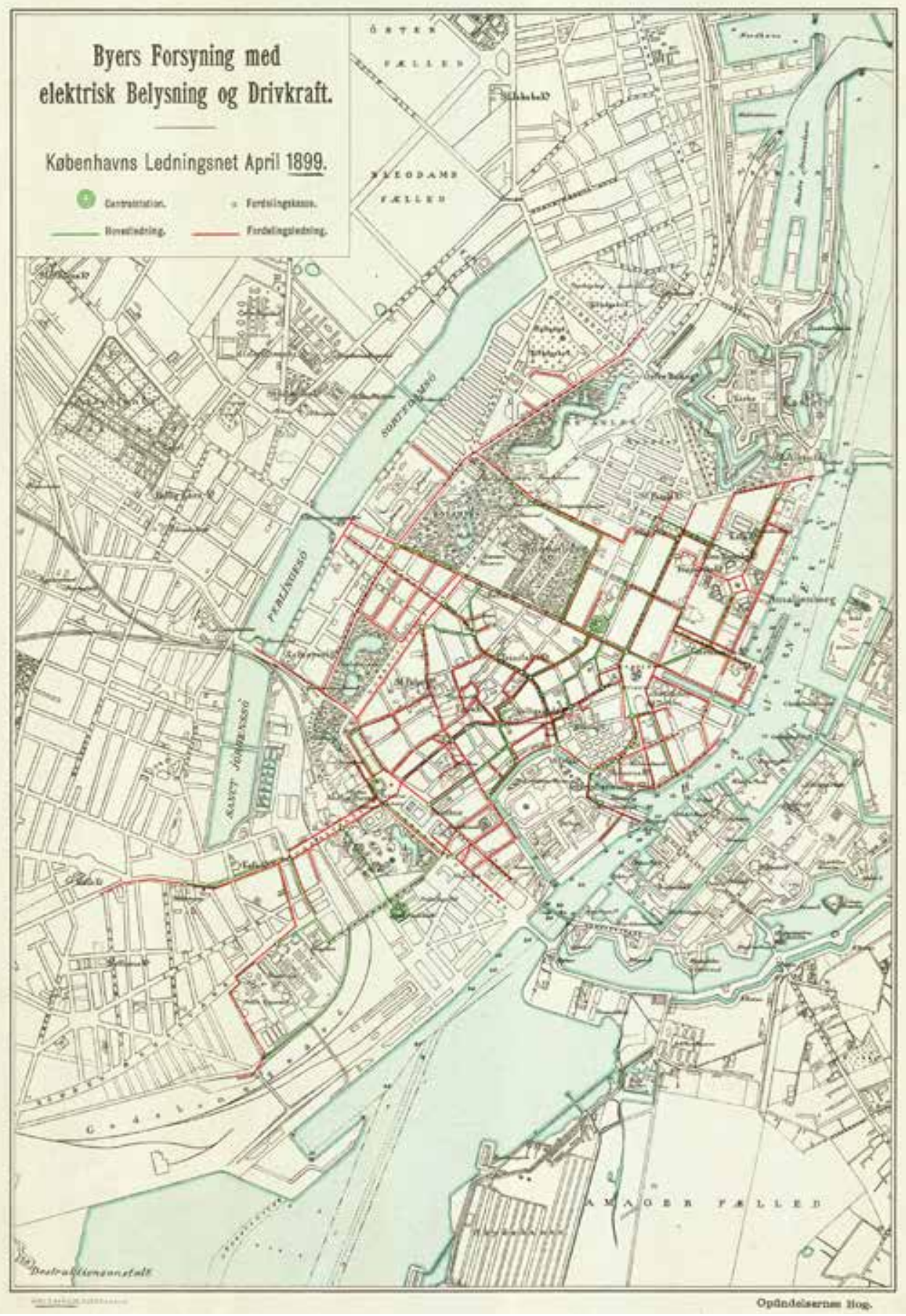

Elektricitetens udbredelse i København 1899. En kortlægning af både de meste prestigiøse og de mest befærdede steder i byen. Fra Opfindelsernes Bog. Det Kongelige Bibliotek.

Forretningsbesøget $i$ den indre By er absolut i tiltagende. For dem, der vil købe i bestemte, ansete Forretninger på Strøget, er det nu langt lettere at få deres Ønske opfyldt, selv om de bo langt borte, hvor de tidligere gjorde de 
fleste Indkjøb i Forretninger, som laa i nærheden ... trafiken med de elektriske Vogne stiger Maaned for Maaned og stiger enormt, det kørende og købende og lejende Publikum er saare tilfreds, men adskillige af de Handlende og af Husejerne føler sig paa gyngende Grund. Det samme gælder adskillige Restaurationer. Næsten paa alle linier lægges det yderste Holdested stedse længere ud, men ved det gamle Holdested blomstrede som regel Restaurationer. Folk kørte helt ud og blev der. Saa snart Holdestedet er flyttet, fare de forbi, længere ud. Et par Restaurationer ved Strandvejen er f.ex. bleven halvt ødelagte ved denne Forholdenes Forrykning. ${ }^{70}$

Byrummet bliver her defineret af forbindelser mellem sporvognenes rækkevidde på den ene side, og på den anden side en udvikling af indre by, den såkaldte citydannelse. ${ }^{71}$ Men en ny mekanisme introduceres her gennem historien om udflytningen af endestationerne. I den voksende by var mekanismen centrifugal: hvis man bekvemt kunne komme længere ud, så gjorde man det. Både hvad angik den rekreative trafik og arbejdstrafikken søgte folk i denne periode ud, så længe der stadig var nem adgang til de forbrugs- og drømmerum, som voksede frem i centrum. Sporvejene fik væsentlig indflydelse på grænserne mellem by og ikke-by ved at definere grænsen for, hvor langt man kunne komme og stadig have adgang til bl.a. cityområdet.

Det leder til et andet eksempel på byens forbindelseskultur: Da man i 1906 oprettede linie 5 i pendulfart mellem det nyligt indlemmede Brønshøj over Rådhuspladsen til Frelser Kirke, var Brønshøj kun et landsbysamfund. Her var i 1899 blevet grundlagt arbejderkolonien Enigheden, beboet af arbejdere på mejeriet af samme navn. Efter pres fra bl.a. disse beboere oprettedes linjen som en af de første pendlerruter, der medvirkede til, at byen blev en af de hurtigst voksende københavnske forstæder. ${ }^{72}$ I modsætning til Brønshøj følte beboerne på Nørre Alle øst for Nørrebrogade sig tværtimod frakoblede. I 1903 henvendte de sig til sporvejsselskabet i et brev under overskriften Et kvarter der venter på en Sporvej. ${ }^{73}$ Her beklagede de den lange vej til centrum, faldet i grundværdi for deres kvarter, og udviklingens generelle stagnation. Beboerne i kvarteret ved Søndre Boulevard indsendte en underskriftindsamling i indbinding og guldtryk med lignende appel. Forbindelse og tilkobling blev afgørende for byboerne, så snart sporvejene havde gjort deres indtog og forbundet andre dele af byen. Forbindelseskulturen viste sig også ved en byudvikling omkring de større sporvejsknudepunkter, som det f.eks. skete omkring Trianglen på Østerbro.

70 Grundejerbladet 14. november 1903.

71 Om citydannelse i danske byer, se f.eks. Toftgaard, 2012; Jørgensen, 1986.

72 Aftenposten d. 9. august 1903.

73 Samfundet d. 7. december 1903. 
De elektriske sporveje havde også deres del i at navigation blev en central del af bykulturen, både socialt og topografisk. Vi kan se det gennem to eksempler, trafikuheld og social omgang i sporvejskupeen. De elektriske sporveje var flere, hurtigere, tungere og ikke mindst mere lydløse end deres hestetrukne forgængere. De blev dødsensfarlige på en måde, man ikke hidtil havde set i byens trafikale historie: de glidende vognkroppe kunne overraske, fastklemme og dræbe mennesker og dyr med en ny brutalitet og hastighed. Samtidens aviser bugner af detaljerede beskrivelser af forvredne kroppe, klippet over eller mast af de elektriske vogne. Som del af en større forandring af byens gader til transportkorridorer skabte de farlige sporveje nye praksisser: man måtte krydse vejen vinkelret og ikke spadsere skråt over - en praksis som i mellemkrigstiden blev indpisket med indførslen af fodgængerovergange. Som noget andet nyt måtte man også vænne sig af med at springe på sporvognen i farten, og man skulle lære at finde sin plads i kupéen. Nogle sæder var for rygere, man måtte ikke spytte indenfor, og i de toetages vogne var overetagen gerne for børn og unge mennesker. Sporvognskupéen og stoppestederne blev rum for en mængde anvisninger, tidstavler og meddelelser hidtil uset i byen. ${ }^{74}$

\section{En elektrisk kulturhistorie?}

Hvis vi ser på de italesættelser, praksisser og materielle koblinger, der omgiver byen og kroppen omkring 1900, kan vi på trods af de forskellige parametre se nogle fællestræk. Hvis vi tager det for gode varer, at der sker en "materialisering” og sammenvævning af krops- og byliv omkring 1900, og at denne bl.a. bliver drevet af nye polytekniske, neurologiske og psykiatriske former for viden, så kan man videre spørge, hvilke konkrete udtryk det giver. På den ene side bliver kroppens og byens rum konstruerede som sammensætninger af energi- og kommunikationsnetværk. Den måde, elektriciteten bliver del af den moderne krop i disse tekster, er som en energi, der altså både "inciterer” kroppen og gør den urolig og overstimuleret som et elektrisk kredsløb. Den er metafor for en strøm eller frekvens, der accelereres og bringes ud af balance med det flimrende sociale liv i den moderne by. Men den elektriske krop viser sig også som rum for kommunikation. Som et "spejl med hundrede flader" registrerer og reflekterer den en flimrende omverden. Nerverne, nervøsiteten og neurastenien spiller en rolle i fremkomsten af denne sammenføjning på det kropslige felt ligesom telegrafen, gadelyset og sporvejene gjorde det for det offentlige byrum.

Er der en særlig grund at fremhæve netop elektrificeringen? Der er andre kraftformer som f.eks. damp og benzin, der også er blevet brugt som metaforer og ram- 
mer for at forstå byen og menneskekroppen. Men det, der gjorde elektriciteten særlig, var dens multiple karakter af energi og kommunikationsmedie på samme tid, som gjorde elektrificeringen mere gennemtrængende i forhold til både byens og kroppens kulturhistorie.

Spørgsmålet om det frugtbare i en sådan kulturhistorie på tværs er forhåbentlig blevet åbnet med ovenstående artikel, om end den kun består i enkelte nedslag fra et kildemateriale, der sikkert kan udvides væsentligt. Men det materiale, der er inddraget, synes jeg, peger allerede på, at der er nye perspektiver i at se et begreb som elektrificering som en sammenføjning af byen og kroppen, og muligvis kunne andre komponenter også frugtbart tilføjes en sådan undersøgelse. Som et eksempel på sådanne nye perspektiver kan vi se, hvordan opmærksomheden omkring et begreb som opladning spænder fra byen til kroppen. Dette kræver en bredere definition af elektrificering, end man oftest har brugt den, men uden at miste prægnans, mener jeg, og i øvrigt heller ikke uden fortilfælde. Således peger for eksempel David Nyes brug af "electrification” meget i samme retning som denne. ${ }^{75}$

Hensigten var således også at åbne for en diskussion af betingelserne for en byhistorie, der i sit begrebsapparat prøver at integrere henholdsvis teknologi- og kulturhistorie. Hvis der nogensinde bliver skrevet en teknologisk kulturhistorie, og den får et kapitel om den moderne by, vil det nemlig være en styrke at bygge et kapitel på en sådan forudgående diskussion.

\section{Litteratur}

Bang, Herman. 1887: Stuk. Kbh. J. H. Schubothe.

Bjørnson, John Kåre. 1988: Linie 1. Hovedstaden Får Trafikselskab. Sporvejshistorisk Selskab.

Buhl, Hans. 2005: Buesenderen. Valdemar Poulsens Radiosystem. Århus Universitetsforlag.

Buhl, Hans, and Henry Nielsen. 1994: "Made in Denmark?: Nye Studier I Dansk Teknologihistorie”. Klim.

Böcher, Sten. 1945: "Danmarks Elektrificering.” Geografisk Tidsskrift.

Dahl, Carl V H, V Faaborg-Andersen, and Th Gelardi. 1939. Elektricitetens Historie. Kbh.

De Landa, Manuel. 2007: A New Philosophy of Society. Assemblage Theory and Social Complexity. Continuum.

Dennis, Richard. 2008: Cities in Modernity Representations and Productions of Metropolitan Space, 1840-1930. Cambridge University Press. 
Feilberg, Ludvig. 1881: Om Størst Udbytte Af Sjælsevner Bidrag Til Praktisk Psykologi. 2. Opl. J. H. Schubothes Boghandel.

Filarski, Ruud. 2011: “A Giant Spider Web, Hanging Full of Dead Flies? The Rise of the Tram.” In Mobility in History. Themes in Transport, edited by Gijs Mom, Peter D Norton, Georgine Clarsen, and Gordon Pirie. Éditions Alphil presses Universitaires suisse.

Faaborg-Andersen, V. 1942: “Elektrificeringen.” In Danmarks Kultur Ved År 1940, Bd. 4. Købehavn.

Garde, Axel. 1908: Dansk Aand. Gjellerup.

Gelardi, Th, ed. 1940: Elektricitetens Historie Og Dens Mænd. Alfred Jørgensens Forlag.

Graham, Stephen, and Simon Marvin. 2001: Splintering Urbanism. Networked Infrastructures, Technological Mobilities and the Urban Condition. Routledge.

Hansen, Børge S. 1992: De Københavnske Elværker. Københavns Belysningsvæsen.

Harnow, Henrik. 2011: "The Role of the Engineer in Danish Modernisation, 1850-1920.” Scandinavian Economic History Review 45:3, s. 224-243.

Hassø, Arthur G. 1931: Københavns Brandvæsens Historie. Københavns Brandforsikring.

Herzig, Rebecca. 2008: "Subjected to the Current: Batteries, Bodies, and the Early History of Electrification in the United States.” Journal of Social History 41 (4), s. 867-885.

Highmore, Ben. 2002: Everyday Life and Cultural Theory. An Introdution. Routledge.

Highmore, Ben 2005: Cityscapes. Cultural Readings in the Material and Symbolic City. Palgrave Macmillan.

Holm, Axel, and Kjeld Johansen. 1941: København 1840-1940 Det Københavnske Bysamfund Og Kommunens Økonomi. Nyt Nordisk Forlag Arnold Busck.

Hughes, Thomas Parke. 1983: Networks of Power. Electrification in Western Society 1880-1930. Softshell. Johns Hopkins University Press.

Hyldtoft, Ole. 1984: Københavns Industrialisering 1840-1914. Systime.

Hyldtoft, Ole. 1994: Den Lysende Gas. Etableringen Af Det Danske Gassystem 1800-1890. Systime.

Hård, Mikael; Thomas J. Misa 2008: "Modernizing European Cities: Technological Uniformity and Cultural Distinction”. Hård, Mikael; Thomas J. Misa (red.): Urban Machinery. Inside Modern European Cities, s. 1-22. MIT Press. Jensen, Sigurd; Claus M Schmidt. 1982: Rammerne Sprænges. 1830-1900. Erik Kjersgaard (red.) Københavns Historie bd. 4, Gyldendal. 
Jørgensen, Caspar 1986: “Aspekter af Citydannelsen i København. En analyse af samspillet mellem funktionsskift og kommercielle bygninger i det indre København ca. 1870-1914”. Københavns Universitet, Amager.

Københavns sporveje 1963: 100 År Sporveje i København. Kbh.

Levin, Miriam (red.) 2010: Urban Modernity. Cultural Innovation in the Second Industrial Revolution. MIT Press.

Ljungquist, Walter 1933: Ombyte Av Tåg. Sth.

Löfgren, Orvar 2008: "Motion and Emotion: Learning to be a Railway Traveller." Mobilities 3 (3) s. 331-351.

Mantegazza, Paolo 1888: Nervøsitetens Aarhundrede. Kbh.

McKay, John 1976: Tramways and Trolleys : The Rise of Urban Mass Transport in Europe. Princeton University Press.

Møller, Jes Fabricius. 2002: “Biologismer.” Historisk Institut. Københavns Universitet.

Nye, David E. 1992: Electrifying America. Social Meanings of a New Technology, 1880-1940. MIT Press.

Olesen, Bodil; Jytte Thorndahl 2004: Da Danske Hjem Blev Elektriske 19002000. Århus: Kvindemuseets Forlag.

Otter, Chris 2008: Victorian Eye : A Political History of Light and Vision in Britain, 1800-1910. University of Chicago Press.

Otter, Chris 2010: "Making Liberalism Durable: Vision and Civility in the Late Victorian City.” Social History 27:1, s. 1-15.

Panum, Peter 1904: Illustreret Lægebog. København.

Pontoppidan, Knud. 1886: Neurasthenien. Bidrag Til Skildringen Af Vor Tids Nervøsitet. Th. Linds Boghandel.

Rabinbach, Aron 1990: The Human Motor: Energy, Fatigue and the Origin of Modernity. Basic Books.

Rode, Jørgen 1942 (red.): Københavns Elektricitetsværker. Københavns Belysningsvæsen.

Røgind, Sven 1913: “Københavns Sporveje Gennem 50 Aar.” Nationaløkonomisk Tidsskrift, 21:3

Brøndum-Nielsen, Johannes (red.):1930. Salmonsens Konversationsleksikon. J. H. Schultz.

Schivelbusch, Wolfgang 1995: Disenchanted Night. The Industrialization of Light in the Nineteenth Century. UCLA Press.

Schott, Dieter 2010. "Empowering European Cities: Gas and Electricity in the Urban Environment”. Mikael Hård and Thomas J Misa (red.): Urban Machinery. Inside Modern European Cities , s.165-186. MIT Press.

Simmel, Georg 1903: "Die Großstadt Und Das Geistesleben.” Die Grossstadt. Vorträge Und Aufsätze Zur Städteausstellung, Band 9, 185-206. Th. Petermann. 
Simonsen, Dorthe Gert 2008: “Transitrum: Flykabiner og supermodernitetens ikke-steder”. Scandia 74:2, s. 103-126.

Thelle, Mikkel 2013: “København 1900. Rådhuspladsen som laboratorium for den moderne bys offentlige rum”. Københavns Universitet.

Thrift, Nigel 1996: Spatial Formations. SAGE Publications.

Toftgaard, Jens 2012: “Citydannelse, butiksstrøg og byidealer”. Institut for Historie, Kultur Og Samfundsbeskrivelse. Syddansk Universitet.

Wagner, Michael; Adri A. Albert de La Bruhéze 2012: "Det Europæiske Fritidsmenneske : Forbruger- Og Forhandlingskrydsfelter I Det 20. Århundredes Fritidsliv”. Den Jyske Historiker 127/128.

Williams, Rosalind 1982: Dream Worlds: Mass Consumption in Late NineteenthCentury France. University of California Press.

Wistoft, Birgitte 1994: "Elektrificeringen af Danmark - træk af dansk elektricitetsforsynings historie”. Hans Buhl; Henry Nielsen (red.) Made in Denmark? Nye Studier I Dansk Teknologihistorie, s. 161-194. Klim.

Wistoft, Birgitte; Henry Nielsen 1998: "Painting Technological Progress: P. S. Krøyer's 'The Industrialists'”. Technology and Culture 39:3 s. 408-433.

Wistoft, Birgitte; Jytte Thorndal; Flemming Petersen; Harriet Hansen 1992: Elektricitetens Århundrede. Dansk Elforsynings Historie. Bd. 1-2. Danske Elværkers Forening.

Zerlang, Martin 2002: Bylivets Kunst. København som Metropol og Miniature. Spring.

\section{Utrykte kilder}

Stadsarkivets erindringer, nr. 1237, Nielsen, Valborg, HA 33, se www.erindringer.dk

\section{English Summary}

Electrification is a central part of the modern city's cultural history. The article investigates the phenomenon with a case in Copenhagens development 18801914, how the early development of electricity took part in a transformation of both urban space and the human body. As two systems, they were both becoming more accepted as artificially sustained and technologically accelerated with the advent of electrical power and networks. This unfinished investigation suggests how a possible cultural history of technology could relate traditional objects of historical study in new ways. 